Przegląd Badań Edukacyjnych Educational Studies Review

ISSN 1895-4308

nr 35 (2/2021), s. 131-151

ORYGINALNE ARTYKULY BADAWCZE

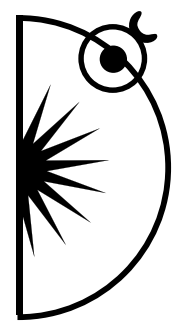

Renata Góralska

University of Lodz, Poland

e-mail: renata.goralska@now.uni.lodz.pl

ORCID: https://orcid.org/0000-0002-0794-8609

Małgorzata Kosiorek

University of Lodz, Poland

e-mail: malgorzata.kosiorek@now.uni.lodz.pl

ORCID: https://orcid.org/0000-0001-8093-6279

\title{
The (Un)presence of Emotions in Teacher Education. A Critical Analysis of the Academic Curriculum Discourse in Poland
}

http://dx.doi.org/10.12775/PBE.2021.035

\begin{abstract}
:
Emotions are an important aspect of teachers' professional work, and therefore, developing their emotional competences is an important element of teacher training. The aim of the article is to answer the question whether, in the process of preparing teachers to perform their professional role, attention is paid to issues related to the emotions. The theoretical perspective of our research is provided by the socio-constructivist concepts of emotions and emotional competences. We refer primarily to the theories of Steven Gordon and Carolyn Saarni. The research problem focuses on the question: how are the emotional competences of teachers constructed/presented in the academic education curriculum in Poland? We searched for an answer to the problem by means of critical discourse analysis (CDA), which is one of the most useful research perspectives for studying the relationship between socio-cultural and discursive changes. The source of discursive data is the document that constitutes the legal basis regulating the teacher education process in Poland, i.e. Regulation of the Minister of Science and Higher Education. Our research revealed that in Polish academic education
\end{abstract}


there is a technical-instrumental discourse in force, which is related to the traditional model of teacher training. This has a decisive impact on both the structure of the teacher training curriculum in Poland and the marginal importance of the role of emotions in teachers' work. The performed analysis may contribute to the improvement of educational practice and, consequently, to the improvement of the quality of academic education.

Keywords: teacher education, emotions, emotional competences, curriculum, discourse analysis.

\section{Introduction}

Emotions are one of the most important aspects of teachers' work. Assuming that all learning is always connected with emotions (Nias, 1996; Hargreaves, 1998a; 1998b; 2002; Boler, 1999; Illeris, 2002; Zembylas, 2004; 2011; Day \& Lee, 2011) the priority is to study and analyse the emotional experiences of teachers (Bruner, 1996; Boler \& Zembylas, 2003; Zembylas, 2003; 2013). In the context of preparation for the performing of tasks in educational institutions, the most frequently quoted category is teachers' competences, including their emotional competences (Day, 2004; Hargreaves \& Fullan, 2012; Madalińska \& Góralska, 2012).

Many researchers (Hargreaves, 1998b; 2000; Kelchtermans, 2005; De Vries et al., 2020) emphasize that developed emotional competences enable teachers to provide students with an appropriate learning environment that will allow them to recognize, understand, and express their emotions in an appropriate way and build the emotional culture of the school (Zembylas, 2006; Boler \& Davis, 2018; Góralska, 2018). The teacher's emotional competences are conducive to the building of better relationships with students and creating an educational environment based on support and social cohesion. By developing emotional competences, the teacher becomes more communicative, tolerant, self-aware, assertive, inquisitive, analytical, and open-minded. Moreover, by developing emotional competences, he or she becomes more aware of his or her own thoughts, feelings, and emotions, and appreciates personal and social development more. In a word, having emotional competences makes it possible for teachers to use their inter-/intrapersonal skills to recognize and understand both their own emotions and the feelings of other people, and to manage them in order to develop positive relationships with others (Noddings, 2011; Madalińska-Michalak \& Góralska, 2012; Góralska, 2020).

Unfortunately, most teachers are not properly prepared to create an authentic and open educational environment, cope with difficult situations, and build 
empathetic interpersonal relationships. Teachers are usually well-prepared to teach specific subjects, but they lack the skills and competences related to selfawareness, assertiveness, tolerance, and self-reflection (Salovey \& Sluyter, 1997; Biesta, 2010; Noddings, 2011; Hargreaves \& Fullan, 2012; Quinlan, 2016; Góralska \& Kosiorek, 2021).

The aim of our research is to find an answer to the question of whether, in the process of preparing teachers for their professional role, attention is paid to issues related to emotional competences and how they are constructed. We are looking for an answer to this question by analysing the document which constitutes the legal basis regulating the teacher training process in Poland, i.e. Regulation of the Minister of Science and Higher Education of 25 July 2019 on the standard of education preparing for the teaching profession.

In our research project, we use Critical Discourse Analysis (CDA) to find out if and to what extent in a university teacher training curriculum there are/ are not any aspects that make up emotional competences. We understand "discourse" as a linguistic action in written or oral communication undertaken by social actors in a specific environment defined by rules, norms, and social conventions (Wodak, 1989). The use of CDA is dictated by the fact that, in our study, we do not limit ourselves only to looking for emotions in the teacher education curriculum. We also want to "reveal" the reasons for their presence or unpresence in the document determining the professional training of teachers in Poland.

We put forward the thesis that the (un)presence of emotions and the way of constructing them in teacher training is a consequence of the fact that in Polish academic education there is a technical-instrumental discourse in force, which has a decisive impact on both the structure of the educational curriculum and the understanding of the role of emotions in teachers' work.

Firstly, in the article, we present the justification and background of our research. Then we present the theoretical assumptions, i.e. teachers' emotional competences in a socio-constructivist perspective. The subsequent part of the text describes the methodological approach and research implementation. In the next section, we perform a critical analysis of the teacher training curriculum in terms of the (un)presence of emotional competences in it. We do this in two ways. Firstly, we are looking for teacher training goals related to emotional competences. Secondly, we reveal/read what model of teacher training dominates the discourse of academic education in the educational curriculum we are analysing.

We hope that our critical analysis of the teacher training curriculum will contribute to the improvement of educational practice and, consequently, to the 
improvement of the quality of academic education, in accordance with the assumption that an important goal of CDA is to develop conclusions and guidelines for changing social practices.

\section{Theoretical framework: the teacher's emotional competences in the socio-constructivist perspective}

As to the theoretical framework, we refer to sociological theories of emotions and to socio-cultural theories, including to Steven Gordon $(1985,1989,1990)$, who was the first to use the term "emotional competence'. Gordon was one of the first theorists to recognize the importance of culture in acquiring emotional experiences. In his view, emotional experience is embedded in interpersonal relationships and has a social nature. In the course of socialization, individuals grow into the emotional culture of a given society, which allows them to be emotionally competent (bolded by Authors) in certain educational situations. Gordon applies the concept of emotional competence to the extent to which individuals in specific contexts defined by a social role understand the emotional messages contained in them. The measure of emotional competence (and thus full socialization) is the ability to accurately read the culturally defined messages.

In the analyses of teachers' emotions, we also refer to the concept of Carolyn Saarni (1998; 1999; 2000), who, like Gordon, develops them significantly, showing how emotional skills are inscribed in human development. The similarity of Gordon's and Saarnia's concepts also results from the adoption by both authors of the same theoretical perspective, i.e. social constructivism. This is essential to the authors' understanding of emotions. In the socio-constructivist model, the main emphasis is on the social context in which emotions are experienced. Emotional development is rooted in interpersonal communication, both verbal and non-verbal. It depends on the beliefs, attitudes, and assumptions characteristic of a given culture; it is the result of observation of significant people and reinforcement systems coming from people with whom individuals are significantly related. All of these factors affect learning what it means to feel something and then react to it. These factors are crucial for the development of emotional competences (Saarni, 1999).

We define emotional competence after Saarni as effectiveness in carrying out emotional social transactions, in other words "it is the ability to engage in transactions in a changing and sometimes unfavourable social and physical environment leading to the development of an individual" (Saarni, 1999, p. 79). The author uses the following categories to describe emotional competence, 
i.e. self-esteem and agency (effectiveness). According to her, self-esteem plays a primary role in explaining the development of emotional competence. Effectiveness, in turn, means the abilities and skills of an individual to achieve a chosen goal. On the other hand, when speaking about "emotion-inducing social transactions", Saarni indicates human emotional responses, which means the strategic use of knowledge about emotions and the ability to express them in contacts with other people (Saarni, 2000).

The teachers' skills that make up emotional competences make it possible for them to control of their own emotional experiences and proper interpersonal exchange with students and other members of the community. The use of the concept of emotional competence makes it possible to indicate what the abilities and skills are related to, which are needed to function in a changing environment and to come out of subsequent trials as better adapted, more flexible, more effective in action, and more self-confident individuals. Saarni distinguishes several components (skills), including the awareness of one's own emotional states; the ability to perceive and differentiate emotions experienced by others, the ability to express emotional experiences; empathy; the knowledge of cultural rules and emotional norms. Emotional competences also include understanding that behaviour expressing emotions affects others and allowing for it in self-presentation strategies; the ability to adaptively deal with aversive or unpleasant emotions; knowing that the nature of interpersonal relationships is determined by the degree of emotional immediacy, authenticity, and a key component of emotional competence, i.e. a sense of emotional efficacy (Saarni, 1998; 1999; 2000).

In this article, we refer to the concept of developing the teacher's emotional competences, developed as part of the international project EL4VET - Teachers First - Using Emotional Literacy to Improve VET Teaching in the $21^{\text {st }}$ Century (Madalińska-Michalak \& Góralska, 2012). This project fits in with the current political focus on 'character' and active citizenship for all. By improving VET teachers' Emotional Literacy we expect to see higher teacher satisfaction, student attainment, and social cohesion; less teacher attrition, student absenteeism and exclusion; all leading to improved job outcomes and emphasis on the crucial role VET plays in a multicultural Europe. It was found out in the project that teachers' competences in working with students are the most important factor determining work in educational institutions. The model for the development of the teacher's emotional competences, developed by the team, constitutes for us a methodological basis for empirical research. Therefore, we assume that the teacher's emotional competences consist of the following ten attributes: empa- 
thy, enthusiasm, forgiveness, optimism, educational power, building interpersonal relationships, self-confidence, social justice, trust, knowledge of youth culture. The aforementioned attributes constitute a tool for us, i.e. the basis for a critical analysis of the teacher education curriculum in Poland.

This analysis will constitute the background for the description of the discourse of education in academic teacher training dominant in Poland. Teacher training and the structure of the curriculum are closely related to different discourses and thus models of being a teacher. The following discourses are distinguished in Polish educational theory: technical-scientific, humanistic, reflective-constructivist, and critical-emancipatory (Gołębniak, 1998; Gołębniak \& Sajdak, 2013; Zamorska, 2014; Klus-Stańska, 2018).

- The technical-scientific discourse is one where the teacher is seen as an adaptive technician. This model is based on behavioural assumptions (Kosiorek, 2007). This means that teaching is treated as a craft requiring high technical qualifications, i.e. knowledge and skills related primarily to the cognitive (intellectual) sphere. Teaching is here a technical activity focused on top-down goals, which can be assigned specific technical strategies for achieving them.

- The humanistic discourse is one in which the influence of Abraham Maslow's (1968) and Carl Rogers' (1956) psychology is clearly visible. In this discourse the central element of the educational process is the learner and his or her subjectivity. The teacher's task is to make it possible for the student to develop and fulfil himself or herself. The teacher acts as a facilitator who approaches the student with acceptance and empathy.

- The reflective-constructivist discourse is one where the teacher is seen as a reflective practitioner (Schön, 1983), who keeps creating his or her own teaching techniques, taking a critical look at his or her own practice, and constantly modifying the methods of pedagogical work. In the concept of reflective practice, the teacher's ability to self-reflect is in the foreground.

- The critical-emancipatory discourse is one where the teacher is seen as a transformative intellectual (Giroux, 1998) and his or her work is closely related to social, economic, and political conditions. Therefore, his or her activity is directed at students, but also has an extracurricular, civic meaning. A critical-emancipatory teacher understands teaching as a kind of social "service", in the name of defending and developing democratic values and social justice (Biesta, 2007; 2010). 
The above-mentioned discourses of academic education also apply to emotional education as broadly understood (Góralska, 2016; 2020). There are also two discourses in emotional education, i.e. adaptive-instrumental and humanistic-critical. The former sees emotional education as developing emotional and social competences. In this approach, competences are treated as a factor facilitating functioning at school, the professional career, and improving functioning in everyday situations. In the latter discourse, emotional experiences are a tool for personal development, and they also have deep social and political entanglements. Here, emotional education is a support for the development of a rich and diverse set of emotional resources that are important both from the perspective of the individual's openness to understanding his/her own experiences and opening the way to personal transformation (Denzin, 1984; Mezirow, 2000, 2003). In the humanistic-critical discourse, it is important to develop empathy, compassion, and solidarity (Biesta, 2007). Activities supporting emotional development understood in this way may contribute to the reduction of suffering, social inequalities, exclusion, and marginalization.

\section{Methodological approach}

The aim of the study is to find emotional competences in the Polish standards of training teachers and to answer the question of how they are presented. This will make it possible for us to determine the reasons for the (un)presence of emotions in the process of teacher training, i.e. to determine the dominant discourse of academic education in Poland. The research problem focuses on the question: How are the emotional competences of teachers constructed in the academic education curriculum in Poland?

We will seek answers to the research problem by means of critical discourse analysis. We treat discourse analysis broadly as a theoretical-methodological framework (approach) covering many different theoretical and research models where the key assumption is the inextricable/close relationship between linguistic and social practice and the symbolic material construction of social reality (Wodak, 1989; Van Dijk, 1993; Meyer \& Wodak, 2001; Kopińska, 2016). We believe that discourse analysis is one of the most useful research perspectives for studying hidden phenomena in education and educational policy, as CDA researchers not only analyse linguistic and textual manifestations and forms of social practice, but also seek to change reprehensible practices (bolded by the Authors). We refer to Norman Fairclough's approach, which focuses on the study of the relationship between socio-cultural and discursive changes as well 
as on the problems of marketization of the system of education, i.e. the implementation of the neoliberal doctrine in organizational discourses (Fairclough \& Wodak, 1997; Fairclough, 1999; 2004).

We have chosen this methodological approach owing to the fact that an active involvement in current topics and phenomena is characteristic of critically oriented discourse analysis. We perceive discourse analysis not only in terms of description and explanation, but also in terms of a political and moral challenge.

In our study, the use of CDA is aimed at examining whether and in what aspects the aspects that make up emotional competences are present/unpresent in a university curriculum of teacher training. Our intention is also to reveal what academic education discourse is present in the professional preparation of teachers. We hope that our critical analysis of the teacher training curriculum will contribute to the improvement of educational practice and, consequently, to the improvement of the quality of academic education.

The source of discursive data in our research is the Regulation of the Minister of Science and Higher Education of 25 July 2019 on the standard of education preparing for the teaching profession. The teacher training curriculum in Poland is a very detailed document, consisting of 129 pages. Our analyses are limited to the effects of education in the teaching profession, and we omit separate standards of education in the professions of kindergarten teachers and teachers of early childhood and school education, special education teachers, and psychologists, identified in the document. For the purposes of this article, we analysed the first part of the document, consisting of 25 pages.

In Poland, there is a centralized system of education, so the teacher training curriculum is top-down determined and strictly regulated by the minister of education, in accordance with the current Act of July 20, 2018 - Law on Higher Education and Science (Journal of Laws 2020, item 85). The curriculum of studies preparing to work as a teacher is a set of rules and requirements in the field of education concerning the way education is organized, and general and specific learning outcomes in relation to knowledge, skills, and competences (attitudes). Therefore, in our research, when looking for elements of emotional competences, we analyse these three categories, i.e. knowledge, skills, and competences.

\section{Results}

In line with the theoretical foundations and methodological assumptions, our research focuses on the critical analysis of the teacher training curriculum. Below, we analyse in detail the teacher training standards in terms of the (un)presence 
of emotional competences in them. Referring to the model of the teacher's emotional competences developed in the EL4VET project, we assume that it consists of the following attributes: empathy, enthusiasm, forgiveness, optimism, educational power, building interpersonal relationships, self-confidence, social justice, trust, and knowledge of youth culture.

\section{The (un)presence of emotions in teacher training curricula}

The analysis of the teacher training curriculum in terms of the (un)presence of emotions in professional preparation shows that teachers' emotions are present in it only to a small extent. Out of 196 learning objectives, only 31 refer to the emotional competence of the teacher. The detailed quantitative presentation of the research results is presented in Table 1.

Table 1. Quantification of educational goals (in terms of: knowledge, skills, competences) in relation to the attributes of the teacher's emotional competences

\begin{tabular}{llcccc}
\hline No. & Attribute & Knowledge & Skills & Competences & Total \\
\hline 1. & Empathy & 1 & 2 & 1 & 4 \\
\hline 2. & Enthusiasm & 2 & 1 & - & 3 \\
\hline 3. & Forgiveness & - & 2 & 1 & 3 \\
\hline 4. & Optimism & 1 & - & 1 & 2 \\
\hline 5. & Power & - & - & - & - \\
\hline 6. & Building Interpersonal Relationships & 2 & 2 & - & 4 \\
\hline 7. & Self-Confidence & 2 & - & - & 2 \\
\hline 8. & Social Justice & 1 & - & - & 1 \\
\hline 9. & Trust & 2 & 1 & - & 3 \\
\hline 10. & Youth Culture & 6 & 3 & - & 9 \\
\hline & Total & 17 & 11 & 3 & 31 \\
\hline
\end{tabular}

Source: Authors' research.

As was indicated in the methodological part, the educational objectives in the teacher training curriculum are related to three categories, i.e. knowledge, skills, and competences. Our research shows that most of the goals related to teachers' emotions, as many as 17 , concern the category of knowledge. 11 goals are related to skills, and only 3 to competences. The interpretation of the data contained in the table shows the existence of large disproportions within the individual at- 
tributes of emotional competences. Most of the learning goals connected with emotions are related to Youth Culture (9), Empathy (4), and Building Interpersonal Relationships (4). We noted three learning goals in the case of Enthusiasm, Forgiveness, and Trust. Not many, because only the 2 learning goals are related to Optimism and Self-Confidence. Social Justice is the least represented. On the other hand, there is no learning goal in the curriculum which is related to Power.

Below, we analyse in detail how the individual attributes of the teacher's emotional competences are "revealed" in the curriculum.

1.1. Empathy - it indicates an important trait of the teacher, which is the ability to empathize and establish appropriate contact with students. It is essential for building proper relations between the teacher and students. This attribute consists of the following teacher skills: the ability to listen carefully to the student; sensitivity to and understanding of the student's otherness; willingness to help people with problems; and the ability to establish contact with students. There are four learning objectives related to empathy in the teacher training curriculum, e.g.: "The ability to show empathy with students and provide them with support and help" (B.2.K1).

In all learning outcomes, empathy is treated instrumentally as a skill that has a specific scope of application, i.e. it serves the achievement of educational goals.

1.2. Enthusiasm - among the most important qualities of a teacher are commitment, enthusiasm, and zeal in sharing his/her knowledge. Enthusiasm makes the subject taught interesting for the student and makes the student engage in the tasks performed. This attribute consists of such teacher's skills as: willingness to share knowledge, willingness to get students involved while working during classes, and the knowledge of various ways of conducting classes. Enthusiasm makes students remember more information presented during a lesson. The teacher's enthusiasm manifests itself to a large extent in the body language, i.e. voice expression, facial expressions, gestures, and movements of the teacher. There are three learning objectives in the teacher training curriculum related to enthusiasm, e.g.: "Ability to cope with stress and use of coping strategies" (B.1.U7).

The above example shows that the teacher's enthusiasm in the analysed curriculum is treated as a trait/quality of the teacher contributing to the achievement of better results in the educational process.

1.3. Forgiveness - this a very important attribute, if the teacher wants to work on improving the relationship with a student with whom a conflict arose previously. Forgiveness is the ability to get rid of negative feelings, such as re- 
sentment, bitterness, exasperation, or anger towards the student, which, if they last long, can cause inappropriate, self-destructive emotions and behaviour. There are three learning objectives in the teacher training curriculum related to forgiveness, e.g.: "Readiness to professionally resolve conflicts in the classroom or educational group" (B.2.K2).

In the analysed curriculum, this extremely important attribute is "expressed" narrowly and superficially, it is treated only as a skill used to resolve conflicts among students. The authors of the curriculum do not see the "potential" of this attribute, nor do they see its importance for the personal development of the teacher himself/herself.

1.4. Optimism - it is an attribute indicating the teacher's need for such qualities as serenity, cheerfulness, joy. This attribute also includes skills such as faith in the positive effect of one's own actions, faith in the students' abilities, but also faith in achieving success. There are two learning objectives in the teacher training curriculum which are related to optimism, e.g.: "Readiness to develop students' curiosity, activity, and cognitive independence as well as logical and critical thinking" (D.1.E.1.K7).

Optimism is treated as a teacher's trait/quality which remains only in the declarative sphere. The authors of the curriculum do not see the important consequences of the teacher's enthusiastic attitude. For example, they fail to see that a cheerful and enthusiastic approach to work can not only help a teacher achieve success, but can also reduce the risk of professional burnout.

1.5. Power - it is understood as the "spiritual" authority of the teacher. The more "spiritual" authority a teacher has, the less physical and mental power he or she has to exercise in order to maintain the authority necessary for education. The point is for the teacher to be aware of the power he or she has, but also (or perhaps above all) of the possibilities and consequences of overusing it in relation to students. The teacher should not abuse power by criticizing, frustrating, or embarrassing students, although he or she may sometimes feel tempted, for example, to reprimand the student or embarrass him or her, if they disrupt the course of the class. It is worth remembering that such a reaction from the teacher usually leads to an escalation of the student's behaviour and causes a series of negative behaviours on the part of the student (the student refuses to follow the instruction, is ashamed, rebels, is aggressive). This kind of "fight" is of no benefit to either the student or the teacher.

In the analysed teacher education curriculum, there is no goal/effect related to the attribute of power. This is a clear proof that the document under examination is governed by a technological discourse in which there are no such 
categories as: "power", "symbolic violence" or "structural violence". These are categories that are used by representatives of critical teaching to describe a teacher's activity.

1.6. Building Interpersonal Relationships - it is an attribute that is associated with the teacher's extensive self-awareness, because only people who understand their own emotions and are aware of their strengths are able to create positive relationships with students (Quinlan, 2016). Other important conditions for creating positive relationships with students include respect for them, trust, empathy, honesty, and the ability to listen to the other person. There are four learning objectives in the teacher training curriculum which are related to building interpersonal relationships, e.g.: "The ability to communicate effectively and consciously" (B.1.U3).

The cited example clearly shows that the ability to build interpersonal relationships is treated instrumentally as an ability to achieve educational goals. There are no other important aspects of establishing a relationship (dialogue) between students and the teacher, based on respect, mutual support, and recognition (Nowak-Dziemianowicz, 2020).

1.7. Self-Confidence - self-confidence is understood here as a trait that is associated with having a certain degree of independence and the ability to cope with difficulties and failures (Wegscheider-Cruse, 2012). There are two learning objectives in the teacher training curriculum which are related to selfconfidence: "Knowledge of the teacher's teaching autonomy" (C.W5).

Self-confidence in the analysed curriculum is presented in a very shallow, perfunctory way, owing to the fact that the two goals included in the curriculum fall under the category of "knowledge". In our opinion, the specificity of this attribute requires taking into account other, more complex skills, such as e.g. self-reflection, critical self-observation, continuous deepening of the understanding of one's professional role, which are absent from the analysed document (Góralska \& Kosiorek, 2021).

1.8. Social Justice - it is the basic condition for the teacher to value and support students' right to be treated with respect. There is only one learning objective in the teacher training curriculum which is related to social justice: "Knowledge about the system of education: national and international regulations concerning the rights of children, students, and people with disabilities, the importance of the school's position as an educational institution, the functions and goals of school education, the concept of the hidden school curriculum, the issue of intra-school law, the core curriculum in the context of the overall curriculum, and educational and preventive activities" (B.2.W1). 
As is the case with self-confidence, the above goal was placed in the category of knowledge and, thus, an important attribute of emotional competences, which is social justice, has been reduced to knowledge about the elements and formal and legal regulations of the system of education. This is in contradiction to defining and understanding this attribute of the teacher's emotional competences, which is not about the knowledge of stereotypes and mechanisms of discrimination, but most of all about skills and attitudes such as acceptance of otherness, tolerance, honesty, and respect for others (Góralska, 2020).

1.9. Trust - it is an attribute that draws attention to the need for the teacher to build an atmosphere of trust and respect in contacts with students. There are three learning objectives related to trust in the teacher training curriculum, e.g.: "knowledge about the teacher's role, teacher's work, and teacher's professional ethics" (B.2.W2).

The above example (and two other effects) are related to the analysed attribute only indirectly. Trust is an open and committed attitude of the teacher; it is also honesty and truthfulness towards students; finally, it is attentive listening and focusing attention on students' problems. Meanwhile, none of these expressions of trust is present in the teacher education curriculum (Kosiorek, 2020).

1.10. Youth Culture - this attribute consists of knowledge about students and the environment which they live in. Knowledge about student/youth culture is the attribute of the teacher's emotional competences which is represented in the analysed curriculum in most cases. As many as nine educational goals are related to youth culture, e.g.: "Knowledge about the special educational needs of students and their conditions" (B.2.W5).

All learning outcomes related to youth culture deal with different aspects of knowledge. Some of them include knowledge about the development of children and young people, others refer to student culture.

Such a large occurrence of learning outcomes in the field of youth culture results from the fact that in the process of teacher training the focus is primarily on objectives related to knowledge. Polish teacher education standards are dominated by learning outcomes in the "knowledge" category. This proves that the teacher is perceived as an "adaptive technician", and the preparation for professional work is instrumental, and mainly comes down to mastering the technically understood knowledge necessary for the teacher's work (Kwaśnica, 2003; Nowak-Dziemianowicz, 2012; Gołębniak \& Zamorska, 2014; Góralska \& Kosiorek, 2021). 


\section{The dominant model of teacher competences in the academic discourse in Poland}

The fact that the emotional competences of the teacher appear in the Polish educational curriculum only to a small extent proves, in our opinion, that it is based on the traditional technical-scientific approach (Ornstein \& Hunkinss, 1989; 2016; Mitchell, 2016; Walker \& Soltis, 2004). This means that the authors of the curriculum mainly care about its being highly objective, universal, and logical. This results from the belief that knowledge is external to the subject of knowledge, which symbolically reflects reality, and also provides the opportunity to precisely define educational ideals. Technical-scientistic curricula are usually constructed by experts and the requirements of science and society are crucial here. The curriculum is a "recipe for action", and is characterized by a high degree of detail. It is an action plan, a list of intended educational outcomes, where there is a rigid division of content into subjects.

In this approach, the curriculum consists of goals and content that are primarily related to the cognitive (intellectual) sphere of the individual's functioning. In a traditionally constructed curriculum, knowledge is understood instrumentally, and the authors of educational curricula use the "should" functor. This means that the educational curriculum is a project of a postulated, better reality. The curriculum is a set of recommendations for their implementation.

The curriculum we are analysing is based on the model of Ralph Tyler (1949), which is deeply embedded in the technical-scientific approach. The model has been criticized for its incompatibility, manageriality, and neoliberal "entanglement". These are trends which, despite numerous attempts at educational reforms, are still dominant in both Polish and global educational practice (Potulicka \& Rutkowiak, 2010; Kosiorek \& Podkówka-Wawrzonek, 2015; Śliwerski, 2017).

The structure of the teacher training curriculum is closely related to the model of the teacher adopted by the authors of the curriculum and the vision of teachers' competences. The curriculum analysed by us is dominated by the traditional model of the teacher, the so-called "adaptive technician". The teacher is seen here as an "omniscient" technologist who uses effective methods and techniques to equip students with knowledge and skills. An 'adaptive technician' teacher believes that teaching content and methodology are key elements in the teaching process. He or she sees his or her role primarily as adapting to the existing educational situation, and along with gaining professional experience, he or she includes in his or her own work model the routine performance of 
assigned tasks. Such a teacher implements the top-down assumptions resulting from the regulations and guidelines of the ministry, and is treated instrumentally as an externally manoeuvrable person who carries out orders without reflection (Kosiorek, 2007; Śliwerski, 2015).

Therefore, in curricula constructed in this way, teachers' knowledge, which includes professional qualifications and methodological skills, comes to the fore. The emotional competences of the teacher occupy a marginal place here. Such a teacher does not have a close relationship with students; he or she focuses primarily on the transfer and enforcement of knowledge. A consequence of such a vision of his or her role is the emotional deficits and problematic behaviour of students as well as disturbances in the socio-emotional climate at school (Ballet \& Kelchtermans, 2009; Day \& Lee, 2011). It is manifested in the lack of positive, enthusiastic interpersonal relations between teachers and students, lack of authenticity and commitment in communication, increasing lack of self-confidence and disturbed self-esteem, and a sense of lack of acceptance, safety, and recognition (Day, 1999; Kelchtermans, 2005).

\section{Conclusions}

The examination of the teacher education curriculum for the presence/absence of emotional competences in university education makes it possible to formulate the following conclusions.

In the process of preparing teachers for their professional roles, emotions are present only to a small extent (out of 196 educational goals, only 31 refer to the emotional competences of the teacher). This clearly shows that the emotional aspects are overlooked and their importance in the teaching profession is underestimated. Our analyses have clearly shown that educational objectives referred to aspects such as Youth Culture Empathy, Building Interpersonal Relationships, Enthusiasm, Forgiveness, and Trust only to a limited extent. It is disturbing that such important emotional competences as Optimism and SelfConfidence are barely highlighted in the teacher training curriculum, and such important aspects of teaching work as Social Justice and Power are absent.

In our opinion, it results from the academic education discourse in force in Poland. According to the thesis presented in the article, the (un)presence of emotions in teacher training is a consequence of the fact that there is the technical-instrumental discourse in force in Polish academic education, and teachers are being prepared to perform their professional roles in accordance with the model of "adaptive technician". This has a decisive impact on both the design 
of the curriculum and the understanding of the role of emotions in the teacher's work. The teacher always participates in some discourse, even if it happens on an unconscious level.

In the technical-instrumental discourse, the teacher's tasks focus primarily on the transfer and verification of knowledge and skills. Therefore, it is not surprising that such categories as Social Justice and Power, which are related to the critical-emancipatory discourse of education, are absent from the curricula. The critical-emancipatory discourse and the related model of a transformative intellectual teacher are almost absent from Polish educational practice (Kosiorek, 2007; Śliwerski, 2015). The domination of technical-scientistic discourse, where the teacher is seen as an adaptive technician, is widely accepted in Polish schools, usually without the awareness that it is not "obvious" or "natural", and that it is not the only one.

\section{References}

Ballet, K., \& Kelchtermans, G. (2009). Struggling with Workload: Primary Teachers' Experience of Intensification. Teaching and Teacher Education, 25, 1150-1157, doi: 10.1016/j.tate.2009.02.012.

Biesta, G.J.J. (2007). Education and the Democratic Person: Towards a Political Understanding of Democratic Education. Teachers College Record, 109(3), 740-769.

Biesta, G.J.J. (2010). Good Education in an Age of Measurement: Ethics, Politics, Democracy. London: Paradigm Publishers.

Boler, M. (1999). Feeling Power: Emotion and Education. New York: Routledge.

Boler, M., \& Davis, E. (2018). The Affective Politics of the "Post-Truth" Era: Feeling Rules and Networked Subjectivity. Emotion, Space and Society, 27, 75-85, doi: 10.1016/j. emospa.2018.03.002.

Boler, M., \& Zembylas, M. (2003). Discomforting Truths: The Emotional Terrain of Understanding Difference. In: P. Trifonas (Ed.), Pedagogies of Difference: Rethinking Education for Social Change (pp. 107-130). New York: Routledge. Retrieved 12 May 2021 from: http://books.scholarsportal.info/viewdoc.html?id=8783.

Bruner, J. (1996). The Culture of Education. Cambridge, MA: Harvard University Press.

Day, C. (1999). Developing Teachers: The Challenges of Lifelong Learning. Bristol: Taylor $\&$ Francis.

Day, C. (2004). A Passion for Teaching. London: Routledge Falmer, doi: 10.4324/9780 203464342. 
Day, C., \& Lee, J.C.K. (2011). New Understandings of Teacher's Work: Emotions and Educational Change. Dordrecht: Springer.

De Vries, B., Swennen, A., \& Dengerink, J. (2020). Design Principles for the Professional Development of Teacher Educators: Illustrations of Narration, Dialogue and Self-Study. Parezja, 1(13), 47-54, doi: 10.15290/parezja.2020.13.05.

Denzin, N.K. (1984). On Understanding Emotion. San Francisco: Jossey Bass.

Fairclough, N. (1995). Critical Discourse Analysis: The Critical Study of Language. London-New York: Longman.

Fairclough, N. (2004). Analysing Discourse. Textual Analysis for Social Research. LondonNew York: Routledge.

Fairclough, N., \& Wodak, R. (1997). Critical Discourse Analysis. In: T.A. van Dijk (Ed.), Discourse as Social Interaction. Discourse Studies: A Multidisciplinary Introduction (pp. 258-284), Vol. 2. London: Sage, doi: 10.4135/9781446289068.

Giroux, H. (1998). Teachers as Intellectuals. Towards Critical Pedagogy of Learning. Connecticut-London: Bergin \& Garney.

Gołębniak, B.D. (1998). Zmiany edukacji nauczycieli. Wiedza - biegłość - refleksyjność [Changes in Teacher Education. Knowledge - Proficiency - Reflectiveness]. Toruń: EDYTOR.

Gołębniak, B.D., \& Zamorska, B. (2014). Nowy profesjonalizm nauczycieli. Podejścia praktyka-przestrzeń rozwoju [Teachers' New Professionalism. Approaches - Practice - Space for Development]. Wrocław: Wydawnictwo Dolnośląskiej Szkoły Wyższej.

Gordon, S.L. (1985). Micro-Sociological Theories of Emotion. In: S.N. Eisenstadt, \& H.J. Helle (Eds.), Micro-Sociological Theory. Perspectives on Sociological Theory (pp. 133-147). Beverly Hills: Sage.

Gordon, S.L. (1989). The Socialization of Children's Emotions: Emotional Culture, Competence, and Exposure. In: C. Saarni, \& P.L. Harris (Eds.), Children's Understanding of Emotion (pp. 319-349). Cambridge: Cambridge University Press.

Gordon, S.L. (1990). Social Structural Effects on Emotions. In: T.D. Kemper (Ed.), Research Agendas in the Sociology of Emotions (pp. 145-179). Albany, NY: State University of New York Press.

Góralska, R. (2016). Kapitał emocjonalny w perspektywie całożyciowego uczenia się: ujęcie adaptacyjne versus krytyczne [Emotional Capital in the Perspective of Lifelong Learning: Adaptive versus Critical Approach]. Rocznik Andragogiczny, 23, 33-48, doi: 10.12775/RA.2016.004. 
Góralska, R. (2018). Kultura emocjonalna. W poszukiwaniu nowych ujęć praktyki szkolnej [Emotional Culture. In Search of New Approaches to School Practice]. Rocznik Pedagogiczny, 41, 63-79, doi:10.2478/rp-2018-000.

Góralska, R. (2020). Emotional Education Discourses: Between Developing Competences and Deepening Emotional (Co-)Understanding. Qualitative Sociology Review, 16(1), 110-125, doi: 10.18778/1733-8077.16.1.08.

Góralska, R., \& Kosiorek, M. (2021). Instrumentalizacja myślenia. O iluzji refleksyjności w kształceniu nauczycieli [Instrumentalization of Thinking. On the Illusion of Reflexivity in Teacher Education]. Kwartalnik Pedagogiczny, 3, in print.

Hargreaves, A. (1998a). The Emotions of Teaching and Educational Change. In: A. Hargreaves, A. Lieberman, M. Fullan, \& D. Hopkins (Eds.), International Handbook of Educational Change (pp. 558-570). The Netherlands: Kluwer, doi: 10.1007/978-94011-4944-0.

Hargreaves, A. (1998b). The Emotional Practice of Teaching. Teaching and Teacher Education, 14, 835-854, doi: 10.1016/S0742-051X(98)00025-0.

Hargreaves, A. (2000). Mixed Emotions: Teachers' Perceptions of Their Interactions with Students. Teaching and Teacher Education, 16, 811-826, doi: 10.1016/S0742$-051 \mathrm{X}(00) 00028-7$.

Hargreaves, A. (2001). Emotional Geographies of Teaching. Teachers College Record, 103(6), 1056-1080, doi: 10.1111/0161-4681.00142.

Hargreaves, A., \& Fullan, M. (2012). Professional Capital: Transforming Teaching in Every School. New York: Teachers College Press, doi: 10.1080/15582159.2012.733288.

Illeris, K. (2002). The Three Dimensions of Learning: Contemporary Learning Theory in the Tension Field Between the Cognitive, the Emotional and the Social. Leicester: NIACE.

Kelchtermans, G. (2005). Teachers' Emotions in Educational Reforms: Self-Understanding, Vulnerable Commitment and Micropolitical Literacy. Teaching and Teacher Education, 21, 995-1006, doi: 10.1016/j.tate.2005.06.009.

Klus-Stańska, D. (2018). Paradygmaty dydaktyki. Myśleć teoria o praktyce [Teaching Paradigms. To Think About Practice Using Theory]. Warszawa: Wydawnictwo Naukowe PWN.

Kopińska, V. (2016). Krytyczna analiza dyskursu - podstawowe założenia, implikacje, zastosowanie [Critical Discourse Analysis - Basic Assumptions, Implications, Application]. Rocznik Andragogiczny, 23, 311-334, doi: 10.12775/RA.2016.016.

Kosiorek, M. (2007). Pedagogika autorytarna. Geneza, modele, przemiany [Authoritarian Pedagogy. Genesis, Models, Transformations]. Kraków: Oficyna Wydawnicza Impuls. 
Kosiorek, M. (2020). Zaangażowanie społeczne nauczycieli w obliczu kultury nieufności [Teachers' Social Commitment in the Face of a Culture of Distrust]. Przeglad Pedagogiczny, 2, 48-57, doi: 10.34767/PP.2020.02.03.

Kosiorek, M., \& Podkówka-Wawrzonek, M. (2015). Professional Teacher's Functions in the Eye of the Neoliberal Ideology of Education. Perspektywy Edukacyjno-Społeczne, 5, $14-18$.

Kwaśnica, R. (2003). Wprowadzenie do myślenia o nauczycielu [An Introduction to Thinking about the Teacher]. In: Z. Kwieciński, \& B. Śliwerski (Eds.), Pedagogika. Podręcznik akademicki. [Pedagogy. An Academic Textbook] (pp. 291-323). Warszawa: Wydawnictwo Naukowe PWN.

Madalińska-Michalak, J., \& Góralska, R. (2012). Kompetencje emocjonalne nauczyciela [Emotional Competences of the Teacher]. Warszawa: Wolters Kluwer.

Maslow, A.H. (1968). Toward a Psychology of Being. New York: D. Van Nostrand.

Meyer, M., \& Wodak, R. (Eds.) (2001). Methods in Critical Discourse Analysis. London: Sage, doi: 10.4135/9780857028020.

Mezirow, J. (2000). Learning as Transformation: Critical Perspectives on a Theory in Progress. San Francisco: Jossey Bass.

Mezirow, J. (2003). Transformative Learning as Discourse. Journal of Transformative Education, 1(1), 58-63, doi: 10.1177/1541344603252172.

Mitchell, B. (2016). Understanding Curriculum. Asian Journal of Humanities and Social Studies, 4(4), 299-311. Retrieved 28 May 2021 from: https://www.ajouronline.com/ index.php/AJHSS/article/view/3928.

MNiSW [Ministry of Science and Higher Education] (2018). Prawo o szkolnictwie wyższym i nauce. Ustawa z dnia 20 lipca 2018 r. (Dz.U. 2018, poz. 1668) [Law on Higher Education and Science. Act of July 20, 2018. Journal of Laws 2020, item 85]. Retrieved 7 July 2021 from: https://isap.sejm.gov.pl/isap.nsf/download.xsp/WDU20180001668/U/ D20181668Lj.pdf.

MNiSW [Ministry of Science and Higher Education] (2019). Rozporządzenie Ministra Nauki i Szkolnictwa Wyższego z dnia 25 lipca 2019 r. w sprawie standardu kształcenia przygotowującego do wykonywania zawodu nauczyciela (Dz.U. 2019, poz. 1450) [Regulation of the Minister of Science and Higher Education of July 25, 2019, on the Standard of Education Preparing for the Teaching Profession. Journal of Laws 2019, item 1450]. Retrieved 7 July 2021 from: http://isap.sejm.gov.pl/isap.nsf/DocDetails. xsp?id=WDU20190001450.

Nias, J. (1996). Thinking About Feeling: The Emotions in Teaching. Cambridge Journal of Education, 26(3), 293-306, doi: 10.1080/0305764960260301. 
Noddings, N. (2011). Stories and Affect in Teacher Education. In: C. Day, \& J.K. Lee (Eds.), New Understandings of Teacher's Work. Professional Learning and Development in Schools and Higher Education (pp. 151-163), Vol. 100. New York: Springer, doi: 10.1007/978-94-007-0545-6_10.

Nowak-Dziemianowicz, M. (2012). Pytania o szkołę, edukację i wychowanie w perspektywie normatywnej [Questions About School, Education and Upbringing in the Normative Perspective]. In: P. Rudnicki, M. Starnawski, \& M. Nowak-Dziemianowicz (Eds.), Władza, sens, działanie. Studia związków ideologii i edukacji [Power, Sense, Action. Studies of Relations Between Ideology and Education] (pp. 31-54). Wrocław: Wydawnictwo Dolnośląskiej Szkoły Wyższej.

Nowak-Dziemianowicz, M. (2020). Szkoła jako przestrzeń uznania [School as a Space of Recognition]. Warszawa: Wydawnictwo Naukowe PWN.

Ornstein, A.C., \& Hunkins, F.P., (1989). Curriculum Innovation and Implementation. Education and Urban Society, 22(1), 105-114, doi: 10.1177/0013124589022001011.

Ornstein, A.C., \& Hunkins, F.P. (2016). Curriculum: Foundations, Principles, and Issues. New Jersey: Pearson Education. Retrieved 28 May 2021 from: https://lib.hpu.edu.vn/ handle/123456789/29248.

Potulicka, E., \& Rutkowiak, J. (2010). Neoliberalne uwiktania edukacji [Neoliberal Entanglements in Education]. Kraków: Oficyna Wydawnicza Impuls.

Quinlan, K.M. (2016). How Emotion Matters in Four Key Relationships in Teaching and Learning in Higher Education. College Teaching, 64(3), 101-111, doi: $10.1080 / 87567555.2015 .1088818$.

Rogers, C.R. (1956). Becoming a Person. Pastoral Psychology, 7, 9-13, doi: 10.1007/ BF01560065.

Saarni, C. (1998). Issues of Cultural Meaningfulness in Emotional Development. Developmental Psychology, 34(4), 647-652, doi: 10.1037/0012-1649.34.4.647.

Saarni, C. (1999). The Development of Emotional Competence. New York: Guilford Press.

Saarni, C. (2000). Emotional Competence: A Developmental Perspective. In: R. Bar-On, \& J.D.A. Parker (Eds.), The Handbook of Emotional Intelligence: Theory, Development, Assessment, and Application at Home, School, and in the Workplace (pp. 68-91). San Francisco: Jossey-Bass.

Sajdak, A. (2013). Paradygmaty kształcenia studentów $i$ wspierania rozwoju nauczycieli akademickich [Paradigms of Educating Students and Supporting the Development of Academic Teachers]. Kraków: Oficyna Wydawnicza Impuls.

Salovey, P., \& Sluyter, D.J. (Eds.) (1997). Emotional Development and Emotional Intelligence: Educational Implications. New York: Basic Books. 
Schön, D. (1983). Reflective Practitioner. How Professionals Think in Action. New York: Basic Books.

Śliwerski, B. (2015). Edukacja (w) polityce. Polityka (w) edukacji. Inspiracje do badań polityki oświatowej [Education (in) Politics. Politics (in) Education. Inspirations for Research Into Educational Policy]. Kraków: Oficyna Wydawnicza Impuls.

Śliwerski, B. (2017). Meblowanie szkolnej demokracji [Furnishing School Democracy]. Warszawa: Wolters Kluwer.

Tyler, R. (1949). Basic Principles of Curriculum and Instruction. Chicago: The University of Chicago Press.

Van Dijk, T.A. (1993). Principles of Critical Discourse Analysis. Discourse \& Society, 4(2), 249-283. Retrieved 13 May 2021 from: https://www.daneprairie.com/.

Walker, D.F., \& Soltis, J.F. (2004). Curriculum and Aims. New York: Teachers College Columbia University Press. Retrieved 20 April 2021 from: http://mehrmohammadi.ir/wp-content/uploads/2019/07/Curriculum-and-Aims.pdf.

Wegscheider-Cruse, S. (2012). Poczucie własnej wartości [Self-Esteem]. Gdańsk: GWP.

Wodak, R. (1989). Language, Power and Ideology. Studies in Political Discourse. Amsterdam: John Benjamins, doi: 10.1075/ct.7.

Zembylas, M. (2003). Caring for Teacher Emotion: Reflections on Teacher Self-Development. Studies in Philosophy and Education, 22, 103-125. Retrieved 20 May 2021 from: https://link.springer.com/article/10.1023/A:1022293304065.

Zembylas, M. (2004). The Emotional Characteristics of Teaching: An Ethnographic Study of One Teacher. Teaching and Teacher Education, 20(2), 185-201, doi: 10.1016/j. tate.2003.09.008.

Zembylas, M. (2006). Challenges and Possibilities in a Postmodern Culture of Emotions in Education, Interchange. A Quarterly Review of Education, 37(3), 251-275, doi: 10.1007/s10780-006-9003-y.

Zembylas, M. (2011). Investigating the Emotional Geographies of Exclusion at a Multicultural School. Emotion, Space and Society, 4, 151-159, doi: 10.1016/j.emospa.2010.03.003.

Zembylas, M. (2013). Critical Pedagogy and Emotion: Working Through 'Troubled Knowledge' in Posttraumatic Contexts. Critical Studies in Education, 54(2), 176-189, doi: 10.1080/17508487.2012.743468. 